\title{
Effect of GA3 and Sitofex (CPPU) Spraying on Yield and Fruit Quality of "Kelsey" Plum Trees (Prunus salicina Lindl.)
}

\author{
Ennab, H. A. and H. M. Abo Ogiela \\ Horticulture Research Institute, Agriculture Research Center, Giza, Egypt \\ Corresponding author: hassan.ennab@yahoo.com
}

\begin{abstract}
A field experiment was conducted during 2018 and 2019 seasons at Abu El-Matamir region, El-Bohaira governorate, Egypt, to study the effect of foliar application of $\mathrm{GA}_{3}$ and sitofex (CPPU) on yield and fruit quality of eight year "Kelsey" plum trees (Prunus salicina Lindl.). Foliar spray of sitofex (CPPU) at 0, 5, 10 and 15 ppm and $\mathrm{GA}_{3}$ at 0,20 and $40 \mathrm{ppm}$ individually or in combination were done twice at full bloom and two weeks other. Twelve treatments were arranged in a randomized complete block design as split plot, gibberellic acid was assigned in the main plots while sitofex (CPPU) was assigned in sub plots. The results showed that, trees sprayed with $\mathrm{GA}_{3}$ at $40 \mathrm{ppm}+\mathrm{CPPU}$ at $15 \mathrm{ppm}$ or $\mathrm{GA}_{3}$ at $20 \mathrm{ppm}+\mathrm{CPPU}$ at $15 \mathrm{ppm}$ significantly increased fruit set $\%$, yield (kg/ tree or ton/feddan) and some fruit physical parameters such as (fruit weight, fruit size and fruit juice). Fruit drop \% was decreased compared to control and other treatments. Chemical fruit quality such as SSC \%, total acidity and SSC/acid ratio were also improved as compared to control. It could be recommended that, "Kelsey" plum trees sprayed with $\mathrm{GA}_{3}$ at $40 \mathrm{ppm}+\mathrm{CPPU}$ at $15 \mathrm{ppm}$ or $\mathrm{GA}_{3}$ at $20 \mathrm{ppm}+\mathrm{CPPU}$ at $15 \mathrm{ppm}$ twice at the full bloom and after two weeks from full bloom which are considered the best combination treatments used to increasing the percentage of fruit size, yield and fruit weight as well as improving the other characteristics of fruit quality.
\end{abstract}

Key words: Prunus salicina, sitofex, CPPU, GA 3 , fruit quality.

\section{Introduction}

"Kelsey" plum (Prunus salicina Lindl.) is grown successfully under Egyptian conditions since 1980; due to its low chilling requirements, adapts to the warm climate and increasing demands of local consumption, fruits ripen in late July with high yield (Hamza et al., 2014). Moreover, plums fruit have high nutritive value in terms of carbohydrates, low in fats and calories, excellent source of vitamins A and $\mathrm{C}$, calcium, magnesium, iron, potassium and fibers (Lozano et al., 2009). Despite its attributes and commercial importance, "Kelsey" plum is still requiring an attention from researchers for further studies to improve productivity and the quality of the fruits. In this respect, fruit size is an important component for plum fruit quality and marketing. Foliar application of bio-regulators like gibberellic acid $\left(\mathrm{GA}_{3}\right)$ and synthetic cytokinin such as sitofex (CPPU) are the best practice for bearing large fruit size and improving other characteristics of fruit quality of plum. Forchlorofenuronis (CPPU) or sitofex a member of the synthetic cytokinin group with phenyl urea structure (Arima et al., 1995). CPPU or N - (2 - Chloro - 4 - pyridyl $)$ - N phenylurea) have successfully improved fruit size in different fruit crops (Guirguis et al., 2010, Banyal $\boldsymbol{e t}$ al., 2013, Fathi et al., 2013 and Hota et al., 2017). The enhancement effect of CPPU on fruit size is due to stimulating cell division in the early stage and promoting cell enlargement in the late stage of fruit development (El Salhy et al., 2009 and Hajam et al., 2018). Moreover, CPPU applications recorded numerous advantages as lick leading fruits more firmly and to more round or oval shape (El Abbasy et al., 2015). Similarly, gibberellins constitute a group of plant hormones that control developmental processes such as germination, shoot elongation, flowering, fruit set, yield and fruit quality (Yamamura et al., 1989; Yehia and Hassan 2005; Kassem et al., 2010; Abd El Baree et al., 2013; Nabil et al., 2013 and Mosa et al., 2015). The main effect of this growth regulator on fruits is enhancing cell elongation and cell enlargement witch increase the fruit length and size (Zoffoli et al., 2009). Therefore, the exogenous applications of CPPU and $\mathrm{GA}_{3}$ aimed to ensure economical yield with a good quality for "Kelsey" plum trees. In this respect, Fathi et al., (2011) reported that foliar sprays of 5 and 10 ppm CPPU alone or in combination with $0 ., 10$ and $20 \mathrm{ppm} \mathrm{GA}_{3}$ at full bloom or fruit set, significantly increased vegetative growth, leaf chlorophyll, yield and fruit quality parameters namely length, diameter, weight, size, firmness, T.S.S. and acidity of "Costata" persimmon. Also, Hifny et al., (2017) revealed that foliar application of Washington Navel orange with CPPU at $4 \mathrm{ppm}+\mathrm{GA}_{3}$ at $30 \mathrm{ppm}$ at full bloom significantly increased fruit set $\%$, retained fruits $\%$ and yield, moreover enhanced fruit physical parameters such as fruit weight, size, length, diameter and fruit juice volume, while the fruit drop percentage was decreased in comparison with untreated trees. Also, it improved fruit biochemical characteristics such as TSS \%, total acidity, TSS/acid ratio and vitamin $C$. In this line, Khot et al., (2015) summarized that, foliar application of CPPU at 2 
$\mathrm{ppm}+\mathrm{GA}_{3}$ at $40 \mathrm{ppm}$ at full bloom stage increased bunch weight and total yield of Thompson seedless grape and also increased berry physical quality parameters namely berry length and diameter as well as juice T.S.S.

Therefore, this investigation was conducted to study the effect of exogenous application of sitofex (CPPU) and $\mathrm{GA}_{3}$ individually or in combinations to improving yield and fruit quality of "Kelsey" plum trees.

\section{Materials and methods}

The present study was carried out in a private orchard at $\mathrm{Abu}$ El-Matamir region, El-Bohaira governorate, Egypt, during 2018 and 2019 seasons in order to study the effect of sitofex (CPPU) and gibberellic acid $\left(\mathrm{GA}_{3}\right)$ alone or in combinations on yield and fruit quality of "Kelsey" plum trees. In this trial, eight years old "Kelsey" plum (Prunus salicina Lindl.) trees budded on Mariana rootstock, and planted at $4 \times 5$ meter apart in calcareous soil under drip irrigation system. The soil texture was sandy (7.73\% clay, $15.19 \%$ silt and $77.08 \%$ sand), 1.38 $\mathrm{dSm}^{-1}$ an electrical conductivity and $\mathrm{pH}$ of 8.15 . Thirty six trees uniform in growth, vigour and productivity were selected, and subjected to the same cultural practices commonly adopted on the orchard. The chosen trees were arranged in a randomized complete block design as split plot, each treatment replicated three times with one tree for each replicate. Main plots were randomly assigned for gibberellic acid $\left(\mathrm{GA}_{3}\right)$ as foliar application at 0,20 and $40 \mathrm{ppm}$. Sub plots were randomly assigned for sitofex (CPPU) as foliar sprays at 0, 5, 10 and 15 ppm. So, this experiment included twelve treatments resulting from the two factors (3 concentrations of $\mathrm{GA}_{3} \times 4$ concentrations of CPPU).

CPPU (N-(2-chloro-4-pyridinyl)-N-phenylurea) solution was prepared from sitofex compound $(0.01 \% \mathrm{CPPU})$ as source of CPPU, while gibberellic acid was used as sodium salt of gibberellic acid (Berlex); each tree was sprayed twice at full bloom and two weeks after from full bloom with $10 \mathrm{~L} /$ tree of the solution at early morning. Four branches per each tree distributed in four directions were tagged for measuring and determination the following parameters:

\section{Fruit set and fruit drop \%:}

Number of flowers, fruitlets at initial set (15 days after full bloom) and the fruits at harvest time were counted on the selected main branches for calculated fruit set and fruit drop percent by the following $\frac{\text { No.of harvested fruits }}{\text { No.of flowers }} \times 100$ equations: Fruit set $\%=$

Fruit drop \%

$=\frac{\text { No. of fruitlets at initial set }- \text { No. of harvested fruits }}{}$

$\times 100$

\section{Yield:}

Yield was harvested at July $26^{\text {th }}$ and $29^{\text {th }}$ in 2018 and 2019, respectively. Yield of each replicate was determined as $\mathrm{kg} /$ tree and ton/feddan. Yield per tree was divided up according to their fruit diameter to three categories, large $>5.0 \mathrm{~cm}$, medium $5.0-4.5$ $\mathrm{cm}$ and small $<4.5 \mathrm{~cm}$.

\section{Fruit quality:}

Twenty fruits were randomly sampled from each replicate to determine fruit quality as fruit weight $(\mathrm{g})$, fruit size $\left(\mathrm{cm}^{3}\right)$ and juice \%. Also, soluble solids content was determined by using hand refractometer, total acidity as malic acid were determined according to (A.O.A.C., 1990) and SSC/acid ratio was estimated.

\section{Statistical analysis:}

The obtained data were subjected to analysis of variance according to Snedecor and Cochran (1990). The differences among treatment means were compared with Duncan multiple range tests (DMRT) at $5 \%$ level according to Duncan (1955).

\section{Results and discussion}

\section{Fruit set \%:}

The results in Table (1) showed significant differences among different concentrations of $\mathrm{GA}_{3}$, CPPU and their interactions on fruit set \% of Kelsey plum trees in both seasons. Spraying $\mathrm{GA}_{3}$ increased significantly fruit set $\%$ as compared to control in both seasons. With regarding $\mathrm{GA}_{3}$ concentrations, data showed that, spraying gibberellic acid at $40 \mathrm{ppm}$ gave the highest percentage fruit set during both seasons. Similar results were obtained by Abd El Baree et al., (2013) and Mosa et al., (2015). In this respect, Nabil et al., (2013) revealed that spraying $\mathrm{GA}_{3}$ at 25 and $50 \mathrm{ppm}$ twice at full bloom and after two weeks on Hollywood and Golden Japanese plum increased fruit set (\%) in both cultivars especially at 50 ppm concentration.

Regarding the effect of spraying CPPU on fruit set $\%$, data in Table (1) cleared that, CPPU had significantly positive effect on fruit set \% than control in both seasons. Application of CPPU at 15 ppm recorded the highest significant values of fruit set followed in a descending order by spraying with 10 and $5 \mathrm{ppm}$, whereas, the lowest values were obtained from control in both seasons. The results are in harmony with the findings of Guirguis et al., (2010) and Hota et al., (2017). Also, Assad (2013) reported that, spraying CPPU at 5 or $10 \mathrm{ppm}$ after one week of full bloom recorded the highest values of fruit set of Hollywood and Santarosa Japanese plum.

The highest fruit set \% was recorded by spraying $\mathrm{GA}_{3}$ at $40 \mathrm{ppm}$ combined with CPPU at $15 \mathrm{ppm}$ followed in a descending order by $\mathrm{GA}_{3}$ at $20 \mathrm{ppm}+$ CPPU at $15 \mathrm{ppm}$ and $\mathrm{GA}_{3}$ at $40 \mathrm{ppm}+\mathrm{CPPU}$ at 10 ppm without significant difference among them in 
both seasons. On the other hand, control treatment gave the lowest values of fruit set $\%$ in both seasons. The increase in fruit set as a result of different concentrations of CPPU and $\mathrm{GA}_{3}$ might be due to its effect on retarding abscission, enhancing resistance to water and nutrient stress and enhanced photosynthesis and mobilization of metabolites to the flowers. This result was supported by Sasaki and Utsunomiya (2002) and Susila et al., (2013). In this line, Khot et al., (2015) revealed that foliar spray with 40 ppm $\mathrm{GA}_{3}+2 \mathrm{ppm}$ CPPU increased fruit set $\%$ of grapevines. Also, Fathi et al., (2011) revealed that, sprays $\mathrm{GA}_{3}$ at $10 \mathrm{ppm}$ combined with $\mathrm{CPPU}$ at 5 or 10 ppm was responsible for maximizing fruit set $\%$ of Costata persimmon trees.

\section{Fruit drop \%:}

Results presented in Table (1) indicate that the percentage of fruit drop was significantly affected by all treatments of $\mathrm{GA}_{3}, \mathrm{CPPU}$ and their interactions on Kelsey plum trees in both seasons. Spraying trees twice at full bloom and after two weeks with $\mathrm{GA}_{3}$ led to significantly decreased fruit drop \%, especially at concentration of $40 \mathrm{ppm}$ in both seasons. On the other hand, the highest percentage of fruit drop was observed on control trees. These results are in accordance with those obtained by Kassem $\boldsymbol{e t}$ al., (2010) and Mosa et al., (2015). In this line, Yamamura et al., (1989) found that the application of $\mathrm{GA}_{3}$ at 25 and $50 \mathrm{ppm}$ significantly reduced fruit drop in Saijo and Fuyu cultivars of persimmon.

As for the effect of CPPU application, it is clear that spraying the trees with CPPU significantly decreased the fruit drop compared to control in both seasons. This decrease was proportional to the concentrations of CPPU. On the other words, the lowest value of this parameter was found in trees sprayed with CPPU at 15 ppm followed by 10 and 5 ppm in both seasons, respectively. On the contrary, the highest percentage of fruit drop was always concomitant to unsprayed trees (control) during 2018 and 2019 seasons. These results are in agreement with the findings of Ahmed and Abd El Aal (2007) and Guirguis et al., (2010). In this respect, Assad (2013) revealed that, spraying of CPPU at 5 or 10 ppm after one week from full bloom recorded the lowest values of fruit drop for Hollywood and Santarosa plum trees.

Table 1. Effect of $\mathrm{GA}_{3}$, sitofex (CPPU) and their interactions on fruit set and fruit drop (\%) of Kelsey plum trees in 2018 and 2019 seasons

\begin{tabular}{|c|c|c|c|c|c|c|c|c|c|c|}
\hline \multirow{2}{*}{$\begin{array}{c}\mathbf{G A}_{3} \\
\text { concentrations } \\
(\mathbf{p p m})\end{array}$} & \multicolumn{4}{|c|}{ Sitofex concentrations (ppm) } & \multirow{2}{*}{$\begin{array}{c}\text { Mean } \\
\text { (A) }\end{array}$} & \multicolumn{4}{|c|}{ Sitofex concentrations (ppm) } & \multirow{2}{*}{$\begin{array}{c}\text { Mean } \\
\text { (A) }\end{array}$} \\
\hline & $\mathbf{0}$ & 5 & 10 & 15 & & $\mathbf{0}$ & 5 & 10 & 15 & \\
\hline \multicolumn{11}{|c|}{ Fruit set (\%) } \\
\hline \multicolumn{6}{|c|}{ Season, 2018} & \multicolumn{5}{|c|}{ Season, 2019} \\
\hline $\mathbf{0}$ & $8.38 \mathrm{f}$ & $16.48 b$ & $14.87 \mathrm{c}$ & $13.63 d$ & $13.34 \mathrm{C}$ & $9.74 \mathrm{~g}$ & $16.88 \mathrm{~d}$ & $14.81 \mathrm{e}$ & $14.22 \mathrm{e}$ & $13.91 \mathrm{C}$ \\
\hline 20 & $12.48 \mathrm{e}$ & $15.61 b c$ & $15.98 b$ & $20.23 a$ & 16.07B & $13.18 \mathrm{f}$ & $18.16 \mathrm{c}$ & $18.28 \mathrm{c}$ & $22.41 \mathrm{a}$ & 18.00B \\
\hline 40 & $13.23 \mathrm{de}$ & $15.77 b c$ & $19.80 \mathrm{a}$ & $20.67 \mathrm{a}$ & $17.36 \mathrm{~A}$ & $14.28 \mathrm{e}$ & $19.54 \mathrm{c}$ & $20.87 b$ & $22.55 \mathrm{a}$ & $19.31 \mathrm{~A}$ \\
\hline Mean (B) & $11.36 \mathrm{D}$ & $15.95 \mathrm{C}$ & $16.88 \mathrm{~B}$ & $18.17 \mathrm{~A}$ & & $12.40 \mathrm{D}$ & 18.19B & $17.98 \mathrm{C}$ & $19.72 \mathrm{~A}$ & \\
\hline \multicolumn{11}{|c|}{ Fruit drop (\%) } \\
\hline \multicolumn{6}{|c|}{ Season, 2018} & \multicolumn{5}{|c|}{ Season, 2019} \\
\hline $\mathbf{0}$ & $62.18 \mathrm{a}$ & $61.18 \mathrm{a}$ & $61.14 \mathrm{a}$ & $60.91 \mathrm{ab}$ & $61.35 \mathrm{~A}$ & $60.24 a$ & $58.42 b$ & $57.63 c$ & $57.30 \mathrm{~cd}$ & $58.39 \mathrm{~A}$ \\
\hline 20 & $61.70 \mathrm{a}$ & $58.67 \mathrm{bc}$ & $57.17 \mathrm{~cd}$ & $54.97 \mathrm{e}$ & $58.12 B$ & $58.51 \mathrm{~b}$ & $55.20 \mathrm{e}$ & $54.21 \mathrm{~g}$ & $53.48 \mathrm{~h}$ & $55.36 \mathrm{~B}$ \\
\hline 40 & $60.73 \mathrm{ab}$ & $57.59 \mathrm{~cd}$ & $56.00 \mathrm{de}$ & $54.59 \mathrm{e}$ & $57.22 \mathrm{C}$ & $57.15 d$ & $54.61 \mathrm{f}$ & $54.36 \mathrm{fg}$ & $52.74 \mathrm{i}$ & $54.71 \mathrm{C}$ \\
\hline Mean (B) & $61.53 \mathrm{~A}$ & $59.14 \mathrm{~B}$ & $58.10 \mathrm{BC}$ & $56.82 \mathrm{C}$ & & $58.63 \mathrm{~A}$ & $56.07 \mathrm{~B}$ & $55.40 \mathrm{C}$ & $54.50 \mathrm{D}$ & \\
\hline
\end{tabular}

Means followed by the same letter within a column are not significantly different using DMRT at $\mathrm{P} \leq 0.05$

Regarding to the interaction, data presented in Table (1) showed that, fruit drop \% was significantly decreased by using all tested treatments on Kelsey plum trees compared to control in both seasons. Moreover, the minimum percentage of fruit drop was recorded with the combination treatment $\mathrm{GA}_{3}$ at 40 $\mathrm{ppm}+\mathrm{CPPU}$ at $15 \mathrm{ppm}$ followed by $\mathrm{GA}_{3}$ at $20 \mathrm{ppm}$ $+\mathrm{CPPU}$ at $15 \mathrm{ppm}$ and $\mathrm{GA}_{3}$ at $40 \mathrm{ppm}+\mathrm{CPPU}$ at 5 ppm as compared with control in both seasons. Similar results were obtained by Sasaki and Utsunomiya (2002) and Hifny et al., (2017) they reported that, spraying $\mathrm{GA}_{3}$ and $\mathrm{CPPU}$ alone or combined together significantly decreased the percentage of fruit drop on mango and orange trees.

It is obvious from data in Table (1) that, fruit set and fruit drop $\%$ of Kelsey plum trees were significantly enhanced by spraying with $\mathrm{GA}_{3}$ and CPPU alone or combined as compared with unsprayed trees in both seasons. Moreover, spraying with $\mathrm{GA}_{3}$ at $40 \mathrm{ppm}+\mathrm{CPPU}$ at $15 \mathrm{ppm}$ or $\mathrm{GA}_{3}$ at 20 $\mathrm{ppm}+\mathrm{CPPU}$ at $15 \mathrm{ppm}$ appeared to be superior in improving fruit set and reducing fruit drop as compared with control. The obtained results are in line with the previously reported by Sasaki and Utsunomiya (2002), Guirguis et al., (2010), Assad (2013), Nabil et al., (2013), Khot et al., (2015) and Mosa et al., (2015). They all stated the positive influence of $\mathrm{GA}_{3}$ and/or CPPU on fruit set and fruit drop of different fruit crops.

3. Yield:

The results in Table (2) showed that, spraying $\mathrm{GA}_{3}$ and CPPU alone or combined together 
significantly increased fruit yield of Kelsey plum expressed as $\mathrm{kg} /$ tree and ton/feddan in both seasons. As for the effect of gibberellic acid, it was evident that gibberellic acid significantly increased the yield as compared with control. Fruit yield as $\mathrm{kg} /$ tree and ton/feddan were significantly increased when $\mathrm{GA}_{3}$ concentration increased especially at $40 \mathrm{ppm}$ as compared to control in both seasons. The obtained results are in line with the findings of Yehia and Hassan (2005), Abd El Baree et al., (2013) and Mosa et al., (2015). In this respect, Nabil et al., (2013) stated that, the using of $\mathrm{GA}_{3}$ at 25 and $50 \mathrm{ppm}$ twice at full bloom and after two weeks on Hollywood and Golden plum trees increased yield of both cultivars especially at $50 \mathrm{ppm}$.
The yield was gradually and significantly increased by increasing the concentration of CPPU in both seasons (Table 2). Spraying CPPU at $15 \mathrm{ppm}$ tended to give the highest values of yield as $\mathrm{kg} /$ tree and ton/feddan followed by 10 and $5 \mathrm{ppm}$ in both seasons, respectively. On the contrary, unsprayed trees (control) produced the lowest values of fruit yield in both seasons. These results are in agreement with those obtained by Ahmed and Abd El Aal (2007) and Banyal et al., (2013), reported that, application of sitofex at 5, 10 and 15 ppm increased the yield of Le Conte pear and apple trees. Also, Guirguis et al., (2010) and Assad (2013) revealed that, persimmon and plum trees sprayed with CPPU at $10 \mathrm{ppm}$ produced higher yield $(\mathrm{kg} / \mathrm{tree})$ than unsprayed trees.

Table 2. Effect of $\mathrm{GA}_{3}$, sitofex (CPPU) and their interactions on yield of Kelsey plum trees in 2018 and 2019 seasons

\begin{tabular}{|c|c|c|c|c|c|c|c|c|c|c|}
\hline \multirow{2}{*}{$\begin{array}{c}\mathbf{G A}_{3} \\
\text { concentrations } \\
(\mathbf{p p m})\end{array}$} & \multicolumn{4}{|c|}{ Sitofex concentrations (ppm) } & \multirow{2}{*}{$\begin{array}{c}\text { Mean } \\
\text { (A) }\end{array}$} & \multicolumn{4}{|c|}{ Sitofex concentrations (ppm) } & \multirow{2}{*}{$\begin{array}{c}\text { Mean } \\
\text { (A) }\end{array}$} \\
\hline & $\mathbf{0}$ & 5 & 10 & 15 & & $\mathbf{0}$ & 5 & 10 & 15 & \\
\hline \multicolumn{11}{|c|}{ Yield (kg/tree) } \\
\hline \multicolumn{6}{|c|}{ Season, 2018} & \multicolumn{5}{|c|}{ Season, 2019} \\
\hline $\mathbf{0}$ & $18.17 \mathrm{~h}$ & $22.57 f$ & $25.67 \mathrm{e}$ & $25.72 \mathrm{e}$ & $23.03 \mathrm{C}$ & $16.18 \mathrm{k}$ & $20.34 \mathrm{i}$ & $24.32 \mathrm{~g}$ & $24.48 \mathrm{~g}$ & $21.33 \mathrm{C}$ \\
\hline 20 & $20.70 \mathrm{~g}$ & $27.48 d$ & $30.50 \mathrm{~b}$ & $34.83 \mathrm{a}$ & $28.37 \mathrm{~B}$ & $19.37 \mathrm{j}$ & $26.24 f$ & $29.76 \mathrm{~d}$ & $35.16 \mathrm{~b}$ & $27.63 \mathrm{~B}$ \\
\hline 40 & $22.77 f$ & $28.97 \mathrm{c}$ & $34.90 \mathrm{a}$ & $35.39 \mathrm{a}$ & $30.50 \mathrm{~A}$ & $21.46 \mathrm{~h}$ & $28.22 \mathrm{e}$ & $34.79 c$ & $35.48 \mathrm{a}$ & $29.98 \mathrm{~A}$ \\
\hline Mean (B) & $20.54 \mathrm{D}$ & $26.34 \mathrm{C}$ & $30.35 \mathrm{~B}$ & $31.98 \mathrm{~A}$ & & $19.00 \mathrm{D}$ & $24.93 \mathrm{C}$ & 29.62B & $31.70 \mathrm{~A}$ & \\
\hline \multicolumn{11}{|c|}{ Total yield (ton/feddan) } \\
\hline \multicolumn{6}{|c|}{ Season, 2018} & \multicolumn{5}{|c|}{ Season, 2019} \\
\hline $\mathbf{0}$ & $3.81 \mathrm{~h}$ & $4.73 \mathrm{f}$ & $5.39 \mathrm{e}$ & $5.40 \mathrm{e}$ & $4.83 \mathrm{C}$ & $3.39 \mathrm{j}$ & $4.27 \mathrm{~h}$ & $5.10 \mathrm{f}$ & $5.14 \mathrm{f}$ & $4.47 \mathrm{C}$ \\
\hline 20 & $4.34 \mathrm{~g}$ & $5.77 \mathrm{~d}$ & $6.40 \mathrm{~b}$ & $7.31 \mathrm{a}$ & $5.95 \mathrm{~B}$ & $4.06 \mathrm{i}$ & $5.51 \mathrm{e}$ & $6.24 c$ & 7.38ab & $5.80 \mathrm{~B}$ \\
\hline 40 & $4.78 \mathrm{f}$ & $6.08 \mathrm{c}$ & $7.32 \mathrm{a}$ & $7.43 \mathrm{a}$ & $6.40 \mathrm{~A}$ & $4.50 \mathrm{~g}$ & $5.92 \mathrm{~d}$ & $7.30 \mathrm{~b}$ & $7.45 \mathrm{a}$ & $6.29 \mathrm{~A}$ \\
\hline Mean (B) & $4.31 \mathrm{D}$ & $5.52 \mathrm{C}$ & $6.37 \mathrm{~B}$ & $6.71 \mathrm{~A}$ & & $3.99 \mathrm{D}$ & $5.23 \mathrm{C}$ & $6.22 \mathrm{~B}$ & $6.65 \mathrm{~A}$ & \\
\hline
\end{tabular}

Means followed by the same letter within a column are not significantly different using DMRT at $\mathrm{P} \leq 0.05$

Regarding the interaction, all treatments significantly increased the yield as compared to control. Moreover, trees sprayed with $\mathrm{GA}_{3}$ at $40 \mathrm{ppm}$ + CPPU at $15 \mathrm{ppm}$ gave better fruit yield than the other treatments followed by trees treated by $\mathrm{GA}_{3}$ at $20 \mathrm{ppm}+\mathrm{CPPU}$ at $15 \mathrm{ppm}$ and $\mathrm{GA}_{3}$ at $40 \mathrm{ppm}+$ CPPU at $10 \mathrm{ppm}$ in both seasons. Otherwise, the control trees gave the lowest yield during the two seasons of the study. The increasing in tree yield might be due to $\mathrm{GA}_{3}$ and CPPU influenced the increase on fruit set, reduce fruit drop (Table 1), positive effect on growth and development of fruits resulted into increase the percentage of large size fruits reached to the stage of harvest (Table 3). Also, an increase in fruit weight and size (Table 4) resulted from accumulation of dry matter in the fruits, rapid cell division and elongation and consequently increased the yield. Similarly, higher yield was obtained by Marvet et al., (2001) on Thompson Seedless' grapevines, following the application of sitofex (CPPU) when applied at 3, 5, $7 \mathrm{ppm}$ alone or in mixture with $\mathrm{GA}_{3}$ at $40 \mathrm{ppm}$. Moreover, Stern et al., (2006) stated that, the improving effect of Sitofex on fruit weight and dimensions, as well as on reducing pre-harvest fruit drop resulted in increased fruit yield in apple trees. These findings related to higher yield with CPPU are in agreement with those obtained by Ahmed and Abd El Aal (2007) in pear trees, Fathi et al., (2011) in persimmon trees and Abd El Raheem et al., (2013) and Hifny et al., (2017) in 'Washington Navel' orange trees.

4. Fruit size distribution:

Results presented in Table (3) show the effect of $\mathrm{GA}_{3}, \mathrm{CPPU}$ and their combinations on fruit size distribution of Kelsey plum fruits. In general, it is clear from Table (3) that, application of gibberellic acid and sitofex produced the larger fruits by $49.28 \%$ followed by medium fruits with 32.60 percent compared to $18.12 \%$ small fruit. Spraying the different concentrations of $\mathrm{GA}_{3}$ and $\mathrm{CPPU}$ as individual application led to significantly decreased small and medium fruits as compared with control, whereas there is no significant variation among concentrations of gibberellic acid and CPPU in the same category. In large fruit category, spraying with $\mathrm{GA}_{3}$ and CPPU significantly increased the large fruit compared to control. This increase is proportional to increase the concentrations of $\mathrm{GA}_{3}$ and CPPU. 
Anyhow, gibberellic acid significantly increased large and medium fruit percent compared to small fruit, whereas there is no significant variation between the two concentrations of gibberellic acid in the same category. Also, Kelsey plum trees sprayed with $\mathrm{GA}_{3}$ at 20 or $40 \mathrm{ppm}$ produce high yield with large fruit size since, the percent reached about $52 \%$ of large fruits.

As for the effect of sitofex (CPPU), the results in Table (3) showed that, application of CPPU at the full bloom and after two weeks was significantly increased the large fruits compared to medium and small fruits. In large fruit category, spraying CPPU at $15 \mathrm{ppm}$ significantly increased the large fruit followed by 10 and $5 \mathrm{ppm}$ compared to control treatment, respectively. On the other hand, all concentrations of CPPU produce lower medium and small fruits as compared to control treatment, but there is no significant variation among CPPU concentrations on this variable under categories of the medium and small fruits.

Table 3. Effect of $\mathrm{GA}_{3}$, sitofex (CPPU) and their interactions on fruit size distribution $\%$ according to diameter of Kelsey plum fruits

\begin{tabular}{|c|c|c|c|c|c|}
\hline \multirow{2}{*}{$\begin{array}{c}\text { GA3 concentrations } \\
(\mathbf{p p m})\end{array}$} & \multicolumn{5}{|c|}{ Sitofex concentrations (ppm) } \\
\hline & $\mathbf{0}$ & 5 & 10 & 15 & Mean (A) \\
\hline \multicolumn{6}{|c|}{ Small fruits (\%) } \\
\hline $\mathbf{0}$ & $29.82 \mathrm{a}$ & $19.61 \mathrm{~d}$ & $18.13 \mathrm{e}$ & $17.74 \mathrm{ef}$ & $21.32 \mathrm{~A}$ \\
\hline 20 & $22.65 \mathrm{~b}$ & $16.97 \mathrm{fg}$ & $14.36 \mathrm{~h}$ & $13.38 \mathrm{hi}$ & $16.84 \mathrm{~B}$ \\
\hline 40 & $21.34 \mathrm{c}$ & $16.08 \mathrm{~g}$ & $14.08 \mathrm{hi}$ & $13.31 \mathrm{i}$ & $16.20 \mathrm{~B}$ \\
\hline Mean (B) & $24.60 \mathrm{~A}$ & $17.55 \mathrm{~B}$ & $15.52 \mathrm{C}$ & $14.81 \mathrm{C}$ & 18.12 \\
\hline \multicolumn{6}{|c|}{ Medium fruits (\%) } \\
\hline $\mathbf{0}$ & $43.35 \mathrm{a}$ & $31.82 \mathrm{~b}$ & $31.21 \mathrm{~b}$ & $31.47 \mathrm{~b}$ & $34.46 \mathrm{~A}$ \\
\hline 20 & $30.19 \mathrm{~b}$ & $31.59 \mathrm{~b}$ & $32.20 \mathrm{~b}$ & $32.47 \mathrm{~b}$ & $31.61 \mathrm{~B}$ \\
\hline 40 & $30.39 \mathrm{~b}$ & $31.79 \mathrm{~b}$ & $32.30 \mathrm{~b}$ & $32.47 \mathrm{~b}$ & $31.73 \mathrm{~B}$ \\
\hline Mean (B) & $34.64 \mathrm{~A}$ & $31.73 \mathrm{~B}$ & $31.90 \mathrm{~B}$ & $32.13 \mathrm{~B}$ & 32.60 \\
\hline \multicolumn{6}{|c|}{ Large fruits (\%) } \\
\hline $\mathbf{0}$ & $26.82 \mathrm{f}$ & $48.49 \mathrm{de}$ & $50.65 \mathrm{~cd}$ & $50.78 \mathrm{bcd}$ & $44.18 \mathrm{~B}$ \\
\hline 20 & $47.15 \mathrm{e}$ & $51.43 \mathrm{abc}$ & $53.43 \mathrm{abc}$ & $54.15 \mathrm{a}$ & $51.54 \mathrm{~A}$ \\
\hline 40 & $48.26 \mathrm{de}$ & $52.12 \mathrm{abc}$ & $53.61 \mathrm{ab}$ & $54.25 \mathrm{a}$ & $52.06 \mathrm{~A}$ \\
\hline Mean (B) & $40.74 \mathrm{D}$ & $50.68 \mathrm{C}$ & $52.56 \mathrm{~B}$ & $53.06 \mathrm{~A}$ & 49.28 \\
\hline
\end{tabular}

Means followed by the same letter within a column are not significantly different using DMRT at $\mathrm{P} \leq 0.05$

Regarding the interaction, the obtained data showed that, trees sprayed with all combination among $\mathrm{GA}_{3}$ and $\mathrm{CPPU}$ concentrations produced higher category of large fruits than control and other treatments. Similar results were obtained by Curry and Greene (1993) and Flaishman et al., (2001) on apple and pear trees. In this respect, Stern et al., (2003) they found that, applying CPPU at $10 \mathrm{ppm}$ after two weeks of full bloom have a significant potential to improve yield and fruit size of 'Royal Gala' apple.

\section{Fruit quality:}

\subsection{Physical characters:}

Data presented in Table (4) cleared that, the highest values of fruit weight $(\mathrm{g})$, fruit size $\left(\mathrm{cm}^{3}\right)$ and fruit juice $(\%)$ were obtained from spraying $\mathrm{GA}_{3}$ at $40 \mathrm{ppm}$ followed by $20 \mathrm{ppm}$ as compared to control. The differences were significant among $\mathrm{GA}_{3}$ concentrations in both seasons. These results agree with those obtained by Yamamura et al., (1989) and Abd El Baree et al., (2013) on persimmon trees. Also, Yehia and Hassan (2005) revealed that the highest fruit weight and fruit volume produced from Le Conte pear trees as a result of sprayed 20 and 40 ppm $\mathrm{GA}_{3}$ at full bloom and three weeks after full bloom. In this line, Hifny et al., (2017) cleared that spraying Washington Navel orange trees by $\mathrm{GA}_{3}$ at 20 or 30 ppm significantly increased fruit physical parameters such as fruit weight $(\mathrm{g})$, fruit size $\left(\mathrm{cm}^{3}\right)$ fruit length, fruit diameter $(\mathrm{cm})$ and fruit juice $\left(\mathrm{cm}^{3}\right)$ in comparison to unsprayed trees.

With regard to the effect of CPPU, the results in Table (4) revealed that fruit weight, size and juice \% were gradually increased by increasing the concentration of CPPU from 0 to $15 \mathrm{ppm}$ with significant differences among them in both seasons. Similar results were reported by El Sabagh (2002) and Guirguis et al., (2010). The increase in fruit weight and size may be due to application of CPPU that plays an important role in enhancing both cell division and elongation as well great role in activating the biosynthesis of proteins, RNA and DNA (Curry and Greene 1993). In this respect, Assad (2013) concluded that spraying of CPPU at 5 or $10 \mathrm{ppm}$ after one week of full bloom recorded the highest values of physical fruit quality characters such as fruit weight, size, length, diameter and firmness of Hollywood and Santarosa plum trees. 
Table 4. Effect of $\mathrm{GA}_{3}$, sitofex (CPPU) and their interactions on physical quality of Kelsey plum fruits in 2018 and 2019 seasons

\begin{tabular}{|c|c|c|c|c|c|c|c|c|c|c|}
\hline \multirow{2}{*}{$\begin{array}{c}\mathbf{G A}_{3} \\
\text { concentrations } \\
(\mathbf{p p m})\end{array}$} & \multicolumn{4}{|c|}{ Sitofex concentrations (ppm) } & \multirow{2}{*}{$\begin{array}{c}\text { Mean } \\
\text { (A) }\end{array}$} & \multicolumn{4}{|c|}{ Sitofex concentrations (ppm) } & \multirow{2}{*}{$\begin{array}{c}\text { Mean } \\
\text { (A) }\end{array}$} \\
\hline & $\mathbf{0}$ & 5 & 10 & 15 & & $\mathbf{0}$ & 5 & 10 & 15 & \\
\hline \multicolumn{11}{|c|}{ Fruit weight (g) } \\
\hline \multicolumn{6}{|c|}{ Season, 2018} & \multicolumn{5}{|c|}{ Season, 2019} \\
\hline $\mathbf{0}$ & 83.511 & $85.27 \mathrm{k}$ & $87.00 \mathrm{~h}$ & $88.48 \mathrm{f}$ & $86.06 \mathrm{C}$ & C $84.35 \mathrm{j}$ & $87.84 \mathrm{~g}$ & $91.62 \mathrm{e}$ & $92.15 d$ & $88.99 \mathrm{C}$ \\
\hline 20 & $85.54 \mathrm{j}$ & $87.76 \mathrm{~g}$ & $92.20 \mathrm{~d}$ & $95.48 b$ & $90.24 \mathrm{~B}$ & $386.51 \mathrm{i}$ & $89.18 \mathrm{f}$ & $94.39 \mathrm{c}$ & $99.18 \mathrm{a}$ & $92.31 \mathrm{~B}$ \\
\hline 40 & $86.54 \mathrm{i}$ & $90.54 \mathrm{e}$ & $95.04 \mathrm{c}$ & $96.13 \mathrm{a}$ & $92.06 \mathrm{~A}$ & A $87.63 \mathrm{~h}$ & $91.61 \mathrm{e}$ & $97.97 \mathrm{~b}$ & $99.23 \mathrm{a}$ & $94.11 \mathrm{~A}$ \\
\hline Mean (B) & $85.19 \mathrm{D}$ & $87.85 \mathrm{C}$ & $91.41 \mathrm{~B}$ & $93.36 \mathrm{~A}$ & & $86.16 \mathrm{D}$ & $89.54 \mathrm{C}$ & $94.66 \mathrm{~B}$ & $96.85 \mathrm{~A}$ & \\
\hline \multicolumn{11}{|c|}{ Fruit size $\left(\mathrm{cm}^{3}\right)$} \\
\hline \multicolumn{6}{|c|}{ Season, 2018} & \multicolumn{5}{|c|}{ Season, 2019} \\
\hline $\mathbf{0}$ & 81.51 & $87.5 \mathrm{~h}$ & $86.7 \mathrm{i}$ & $88.2 \mathrm{~g}$ & $86.0 \mathrm{C}$ & 83.31 & $94.2 \mathrm{i}$ & $01.7 \mathrm{~g}$ & $102.1 \mathrm{f}$ & $95.3 \mathrm{C}$ \\
\hline 20 & $85.5 \mathrm{k}$ & $88.7 f$ & $95.7 d$ & $104.0 \mathrm{~b}$ & $93.5 \mathrm{~B}$ & $89.6 \mathrm{k}$ & $97.6 \mathrm{~h}$ & $04.4 \mathrm{~d}$ & $116.6 \mathrm{~b}$ & 102.1B \\
\hline 40 & $86.5 \mathrm{j}$ & $93.6 \mathrm{e}$ & $103.8 \mathrm{c}$ & $104.5 \mathrm{a}$ & $97.1 \mathrm{~A}$ & $90.8 \mathrm{j}$ & $104.3 \mathrm{e}$ & $16.0 \mathrm{c}$ & $117.1 \mathrm{a}$ & $107.1 \mathrm{~A}$ \\
\hline Mean (B) & $84.5 \mathrm{D}$ & $89.9 \mathrm{C}$ & $95.4 \mathrm{~B}$ & 98.9A & & $87.9 \mathrm{D}$ & $98.7 \mathrm{C}$ & $07.4 \mathrm{~B}$ & $111.9 \mathrm{~A}$ & \\
\hline \multicolumn{11}{|c|}{ Fruit juice \% } \\
\hline \multicolumn{6}{|c|}{ Season, 2018} & \multicolumn{5}{|c|}{ Season, 2019} \\
\hline 0 & $29.20 \mathrm{i}$ & $29.81 \mathrm{~h}$ & $30.42 \mathrm{~g}$ & $30.94 \mathrm{e}$ & $30.09 \mathrm{C}$ & $30.65 \mathrm{i}$ & $31.92 \mathrm{~g}$ & $33.30 \mathrm{e}$ & $33.49 d$ & $32.34 \mathrm{C}$ \\
\hline 20 & $29.91 \mathrm{~h}$ & $30.69 f$ & $32.23 \mathrm{c}$ & $33.38 b$ & $31.55 \mathrm{~B}$ & $331.44 \mathrm{~h}$ & $32.41 \mathrm{f}$ & $34.30 \mathrm{c}$ & $36.00 \mathrm{a}$ & $33.53 \mathrm{~B}$ \\
\hline 40 & $30.26 \mathrm{~g}$ & $31.66 \mathrm{~d}$ & $33.23 b$ & $33.61 \mathrm{a}$ & $32.19 \mathrm{~A}$ & A $31.85 \mathrm{~g}$ & $33.29 \mathrm{e}$ & $35.60 \mathrm{~b}$ & $36.06 \mathrm{a}$ & $34.20 \mathrm{~A}$ \\
\hline Mean (B) & 29.79D & $30.72 \mathrm{C}$ & $31.96 \mathrm{~B}$ & $32.64 \mathrm{~A}$ & & 31.31D & $32.54 \mathrm{C}$ & $34.40 \mathrm{~B}$ & $35.18 \mathrm{~A}$ & \\
\hline
\end{tabular}

Means followed by the same letter within a column are not significantly different using DMRT at $\mathrm{P} \leq 0.05$

The interaction effect between spraying $\mathrm{GA}_{3}$ and CPPU concentrations was significant in both seasons. Data in Table (4) indicated that spraying Kelsey plum trees with combination of $\mathrm{CPPU}$ and $\mathrm{GA}_{3}$ improved the fruit physical characteristics such as fruit weight $(\mathrm{g})$, fruit size $\left(\mathrm{cm}^{3}\right)$ and juice $\%$ in the two studied seasons. The highest values of fruit weight, size and juice \% were obtained by using $\mathrm{GA}_{3}$ at $40 \mathrm{ppm}+\mathrm{CPPU}$ at $15 \mathrm{ppm}$ followed by $\mathrm{GA}_{3}$ at 20 $\mathrm{ppm}+\mathrm{CPPU}$ at $15 \mathrm{ppm}$ and $\mathrm{GA}_{3}$ at $40 \mathrm{ppm}+\mathrm{CPPU}$ at $10 \mathrm{ppm}$ in both seasons, respectively. These results are in harmony with those reported by Yahata $\boldsymbol{e t}$ al., (2006), Fathi et al., (2011) and Abd El Raheem et al., (2013) on different fruit crops. Also, Hifny et al., (2017) reported that spraying Washington Navel orange trees with $\mathrm{GA}_{3}$ at $30 \mathrm{ppm}+\mathrm{CPPU}$ at $4 \mathrm{ppm}$ at full bloom gave the highest values of yield $(\mathrm{kg}) /$ tree and fruit physical properties in terms of fruit weight $(\mathrm{g})$, fruit size $\left(\mathrm{cm}^{3}\right)$ fruit length, fruit diameter $(\mathrm{cm})$ and fruit juice $\left(\mathrm{cm}^{3}\right)$ compared to unsprayed trees.

\subsection{Chemical characters:}

The results in Table (5) indicated that, spraying $\mathrm{GA}_{3}$ at 20 and 40 ppm caused a significantly increased in soluble solids content (SSC \%), SSC/acid ratio and decreased total acidity as compared with control. This effect was more pronounced with the using of $\mathrm{GA}_{3}$ at $40 \mathrm{ppm}$. These results are in agreement with those obtained by Yehia and Hassan (2005), Nabil et al., (2013) and Hajam et al., (2018).

As for the effect of CPPU, the results in Table 5 revealed that SSC\% was significantly decreased with increasing CPPU concentration, while total acidity was slightly increased without significant differences in most cases with increasing sitofex concentration in both seasons. In this respect, the lowest values of SSC/acid ratio were recorded on trees sprayed with CPPU at $5 \mathrm{ppm}$ followed in an ascending order by spraying with CPPU at 10 and 15 ppm, while, the highest values were obtained from control in both seasons. These results are agreed with Ahmed and Abd El Aal (2007) on Le Conte pear, El Sabagh (2002) on apple, Guirguis et al., (2010) on persimmon and Assad (2013) on Hollywood and Santarosa plum trees.

In regarding to the interaction, data presented in Table 5 showed that SSC\%, total acidity and SSC/acid ratio were significantly affected by using all tested treatments on Kelsey plum trees compared to control in both seasons. Moreover, the minimum percent of SSC and SSC/acid ratio were recorded with CPPU at $15 \mathrm{ppm}$ followed in an ascending order by CPPU at $10 \mathrm{ppm}$ and CPPU at $5 \mathrm{ppm}$ as compared with control in both seasons. On contrary that, the maximum acidity was recorded by CPPU at $15 \mathrm{ppm}$ followed in a descending order by CPPU at 10 and 5 ppm as compared with control in both seasons. So, it is obvious from above results that sitofex and $\mathrm{GA}_{3}$ expresses promoted variation effects between treatments; this means that, the use of CPPU either singly or in combination with $\mathrm{GA}_{3}$ delayed fruit maturity. These finding confirmed the former results obtained by Sasaki and Utsunomiya (2002), Guirguis et al., (2010), Fathi et al., (2011), Abd El Raheem et al., (2013) and Hifny et al., (2017) on different fruit crops, they found that, spraying sitofex (CPPU) and $\mathrm{GA}_{3}$ delay fruit maturity compared with unsprayed 
Table 5. Effect of $\mathrm{GA}_{3}$, sitofex (CPPU) and their interactions on chemical quality of Kelsey plum fruits in 2018 and 2019 seasons

\begin{tabular}{|c|c|c|c|c|c|c|c|c|c|c|}
\hline \multirow{2}{*}{$\begin{array}{c}\mathbf{G A}_{3} \\
\text { concentrations- } \\
(\mathbf{p p m})\end{array}$} & \multicolumn{4}{|c|}{ Sitofex concentrations (ppm) } & \multirow{2}{*}{$\begin{array}{c}\text { Mean } \\
\text { (A) }\end{array}$} & \multicolumn{4}{|c|}{ Sitofex concentrations (ppm) } & \multirow{2}{*}{$\begin{array}{c}\text { Mean } \\
\text { (A) }\end{array}$} \\
\hline & $\mathbf{0}$ & 5 & 10 & 15 & & $\mathbf{0}$ & 5 & 10 & 15 & \\
\hline \multicolumn{11}{|c|}{ SSC \% } \\
\hline \multicolumn{6}{|c|}{ Season, 2018} & \multicolumn{5}{|c|}{ Season, 2019} \\
\hline $\mathbf{0}$ & $12.11 \mathrm{c}$ & $11.58 \mathrm{~g}$ & $11.41 \mathrm{~h}$ & $11.15 \mathrm{i}$ & $11.56 \mathrm{C}$ & $12.09 \mathrm{c}$ & $11.62 \mathrm{~h}$ & $11.46 \mathrm{i}$ & $11.31 \mathrm{j}$ & $11.62 \mathrm{C}$ \\
\hline 20 & $12.30 \mathrm{~b}$ & $11.87 f$ & $11.90 \mathrm{ef}$ & 11.94de & $12.02 \mathrm{~B}$ & $12.27 \mathrm{~b}$ & $11.80 \mathrm{~g}$ & $11.85 \mathrm{f}$ & $11.90 \mathrm{e}$ & $11.95 \mathrm{~B}$ \\
\hline 40 & $12.45 \mathrm{a}$ & $11.95 \mathrm{de}$ & $11.95 \mathrm{de}$ & $11.90 \mathrm{ef}$ & $12.07 \mathrm{~A}$ & $12.50 \mathrm{a}$ & $11.90 \mathrm{e}$ & $11.93 \mathrm{de}$ & $11.95 \mathrm{~d}$ & $12.07 \mathrm{~A}$ \\
\hline Mean (B) & $12.28 \mathrm{~A}$ & $11.80 \mathrm{~B}$ & $11.76 \mathrm{C}$ & $11.66 \mathrm{D}$ & & $12.28 \mathrm{~A}$ & $11.77 \mathrm{~B}$ & $11.74 \mathrm{C}$ & $11.72 \mathrm{C}$ & \\
\hline \multicolumn{11}{|c|}{ Acidity \% } \\
\hline \multicolumn{6}{|c|}{ Season, 2018} & \multicolumn{5}{|c|}{ Season, 2019} \\
\hline $\mathbf{0}$ & $0.92 \mathrm{ab}$ & $0.94 \mathrm{ab}$ & $0.96 \mathrm{a}$ & $0.97 a$ & $0.94 \mathrm{~A}$ & $0.94 b c$ & $0.97 \mathrm{ab}$ & $0.98 \mathrm{a}$ & $1.00 \mathrm{a}$ & $0.97 \mathrm{~A}$ \\
\hline 20 & $0.86 \mathrm{~cd}$ & $0.90 \mathrm{bc}$ & $0.85 \mathrm{~cd}$ & $0.84 \mathrm{~d}$ & $0.86 \mathrm{~B}$ & $0.81 \mathrm{f}$ & $0.93 c$ & $0.89 \mathrm{~d}$ & $0.84 \mathrm{ef}$ & $0.86 \mathrm{~B}$ \\
\hline 40 & $0.81 \mathrm{~d}$ & $0.86 \mathrm{~cd}$ & $0.85 \mathrm{~cd}$ & $0.82 \mathrm{~d}$ & $0.83 \mathrm{~B}$ & $0.77 \mathrm{~g}$ & $0.93 c$ & $0.87 \mathrm{de}$ & $0.84 \mathrm{ef}$ & $0.85 \mathrm{~B}$ \\
\hline Mean (B) & $0.86 \mathrm{~B}$ & $0.90 \mathrm{~A}$ & $0.88 \mathrm{AB}$ & $0.87 \mathrm{~B}$ & & $0.84 \mathrm{~B}$ & $0.94 \mathrm{~A}$ & $0.91 \mathrm{~A}$ & $0.89 \mathrm{AB}$ & \\
\hline \multicolumn{11}{|c|}{ SSC/acid ratio } \\
\hline \multicolumn{6}{|c|}{ Season, 2018} & \multicolumn{5}{|c|}{ Season, 2019} \\
\hline $\mathbf{0}$ & $13.16 \mathrm{~d}$ & $12.31 \mathrm{e}$ & $11.88 \mathrm{f}$ & $11.49 \mathrm{f}$ & $12.21 \mathrm{C}$ & $12.85 \mathrm{f}$ & $11.97 \mathrm{~g}$ & $11.73 \mathrm{~g}$ & $11.31 \mathrm{~h}$ & $11.96 \mathrm{C}$ \\
\hline 20 & $14.30 \mathrm{bc}$ & $13.18 \mathrm{~d}$ & $13.99 \mathrm{c}$ & $14.21 b c$ & $13.92 \mathrm{~B}$ & $15.14 b$ & $12.68 f$ & $13.31 \mathrm{e}$ & $14.16 \mathrm{c}$ & $13.82 \mathrm{~B}$ \\
\hline 40 & $15.36 \mathrm{a}$ & $13.89 \mathrm{c}$ & $14.09 \mathrm{c}$ & $14.51 \mathrm{~b}$ & $14.46 \mathrm{~A}$ & $16.23 \mathrm{a}$ & $12.79 \mathrm{f}$ & $13.70 \mathrm{~d}$ & $14.22 \mathrm{c}$ & $14.23 \mathrm{~A}$ \\
\hline Mean (B) & $14.27 \mathrm{~A}$ & $13.13 \mathrm{C}$ & $13.32 \mathrm{~B}$ & $13.40 \mathrm{~B}$ & & $14.74 \mathrm{~A}$ & $12.48 \mathrm{D}$ & $12.91 \mathrm{C}$ & $13.23 \mathrm{~B}$ & \\
\hline
\end{tabular}

Means followed by the same letter within a column are not significantly different using DMRT at $\mathrm{P} \leq 0.05$

\section{Conclusions}

It could be concluded that, spraying "Kelsey" plum trees with $\mathrm{GA}_{3}$ and CPPU at different concentrations significantly increased fruit set, yield and gave the heaviest and largest fruits as well as reduced fruit drop compared to unsprayed trees. Also, spraying $\mathrm{GA}_{3}$ and $\mathrm{CPPU}$ led to improve $\mathrm{SSC}$ $(\%)$, total acidity $(\%)$ and SSC/acid ratio in fruit juice. The best fruit characters and total yield were obtained with $\mathrm{GA}_{3}$ at $40 \mathrm{ppm}+\mathrm{CPPU}$ at $15 \mathrm{ppm}$ or $\mathrm{GA}_{3}$ at $20 \mathrm{ppm}+\mathrm{CPPU}$ at $15 \mathrm{ppm}$ applications.

\section{References}

A.O.A.C. (1990). Association of Official Analytical Chemists. Official Methods of Analysis. 15th Ed. Washington D.C., USA.

Abd El Baree, A.; M. M. Nasr and M. A. Fathi (2013). Improving growth, fruit set, yield, fruit quality and shelf life of "Costata" persimmon. Egypt. J. Hort., 40(2):295 - 311.

Abd El Raheem, M. E; G. F. Abd El- Rahman; H. M. Mohamed and S. B. El Harony (2013). Regulation of Navel orange cropping and improvement of fruit quality using sitofex and gibberellic acid. Nature and Science, 11(6):13-21.

Ahmed, F. F. and A. M. K. Abd El Aal (2007). Effect of concentrations and date of spraying Sitofex (CPUU) on yield and quality of Le-Conte pear fruits. African Crop Science Conference, ElMinia Egypt, 27 - 31 October Proceedings, 8: 523 $-527$.

Arima, Y.; K. Oshima and K. Shudo (1995). Evalution of a novel urea-cytokinin: Horticultural uses of forchlorfenuron. Acta Horticulturae, 394:75 - 84 .

Assad, S.A. (2013). Effect of CPPU on fruit set, drop, yield and fruit quality of Hollywood and Santarosa plum cultivars. Egypt. J. Hort., 40(2):187 - 204.

Banyal, A. K.; R. Raina and R. K. Kaler (2013). Improvement in fruit set, retention, weight and yield of apple cv. Royal delicious through foliar application of plant growth regulators. J. Krishi Vigyan, 2(1): $30-32$.

Curry, E. A. and D. W. Greene (1993). CPPU influences fruit quality, fruit set, return bloom, and preharvest drop of apples. HortScience, 28(2): $115-119$.

Duncan, D.B. (1955). Multiple ranges and multiple F. test. Biometries.11: 1- 42 .

El Abbasy, U. K.; S. M. Al Morsi; F. E. Ibrahim and M. H. Abd El Aziz (2015). Effect of gibberellic acid, sitofex and calcium chloride as preharvest applications on storability of "Thompson seedless" grapes. Egypt. J. Hort., 42(1):427 - 440.

El Sabagh, A. S. (2002). Effect of sitofex (CPPU) on "Anna" apple fruit set and some fruit characteristics. Alex. J. Agric. Res., 47(3):85 - 92.

El Salhy, A. M.; K. A. Amen; A. B. Alaa and E. A. A. Abo Zeed (2009). Effect of berry thinning, CPPU spraying and pinching on cluster and berry quality of two grapevine cultivars. Assiut $\mathbf{J}$. Agric. Sci., 40 (4):92 - 107.

Fathi M. A.; A. I. Mohamed and. A. Abd El-Bary (2011). Effect of sitofex (CPPU) and $G_{3}$ spray on fruit set, fruit quality, yield and monetary 
value of "Costata" persimmon. Nature and Science, 9(8):40 - 49.

Fathi, M. A.; S. A. Asad; W. A. Nabeel and A. Abd El-Baree (2013). Effect of CPPU, GA , $_{3}$, milagrow and pepton on yield and quality of "LeConte" pear trees. Egypt. J. Hort., 40(2):173 185.

Flaishman, M. A.; S. A. Shargal and R. A. Stern (2001). The synthetic cytokinin CPPU increases fruit size and yield of 'Spadona' and 'Costia' pear (Pyrus communis L.). Journal of Horticultural Science \& Biotechnology, 76(2):145 - 149.

Guirguis, N. S.; E. S. Attala; G. B. Mikhael and M. A. Gabr (2010). Effect of sitofex (CPPU) on fruit set, yield and fruit quality of "Costata" persimmon trees. J. Agric. Res. Kafr El-Sheikh Univ., 36(2):206 - 219.

Hajam, M. A.; G. I. Hassan; E. A. Parray; M. A. Wani; A. Shabir; I. F. Khan; A. W. Wani; T. A. Bhat and L. Masoodi (2018). Transforming fruit production by plant growth regulators. Journal of Pharmacognosy and Phytochemistry, 7(1): $1613-1617$

Hamza, A. Y.; A. M. Z. Mesalam and H. A. Tarfaya (2014). Cultivation and Production of Plums. Ministry of Agriculture and Land Reclamation, Agriculture Research Center, Horticulture Research Institute, Central Administration for Agricultural extension Service, Egypt. Technical Bulletin No. 1313 pp: 1 - 52. (In Arabic).

Hifny, H. A.; S. M. Khalifa; A. E. Hamdy and A. N. Abd El-Wahed (2017). Effect of CPPU and GA3 on fruiting and fruit quality of Washington Navel orange. Nature and Science, 15(6):95 - 102.

Hota, D.; D. P. Sharma and N. Sharma (2017). Effect of forchlorfenuron and N-acetyl thiazolidine 4-carboxylic acid on vegetative growth and fruit set of apricot (Prunus armeniaca L.) cv. New Castle. Journal of Pharmacognosy and Phytochemistry, 6(2):279 - 282.

Kassem, H. A.; A. M. El-Kobbia; H. A. Marzouk and M. M. El- Sebaiey (2010). Effect of foliar sprays on fruit retention, quality and yield of Costata persimmon trees. Emir. J. Food Agric., 22 (4):259- 274.

Khot, A. P.; S. D. Ramteke and M. B. Deshmukh (2015). Significance of foliar spraying with gibberellic acid (40\% WSG) and CPPU (1\% SP) on yield, quality, leaf photosynthesis and biochemical changes in grapes. International Journal of Tropical Agriculture, 33(2):221 - 227.

Lozano, M.; M. C. Vidal-Aragon; M. T. Hernandez; M. C. Ayuso; M. J. Bernalte; J. Garcia and B. Velardo (2009). Physicochemical and nutritional properties and volatile constituents of six Japanese plum (Prunus salicina Lindl.) cultivars. Eur. Food Res. Technol., 228(3):403 - 410.
Marvet, A. K.; A. Ali; H. Ibrahim and I. A. Rizk (2001). Effect of CPPU on yield and bunch quality of Thompson seedless grapevines. Egyptian Journal of Agricultural Research, 79 (2): $531-550$.

Mosa, W. F. A.; N. A. Abd El Megeed; M. A. M. Aly and L. S. Paszt (2015). The influence of NAA, $\mathrm{GA}_{3}$ and calcium nitrate on growth, yield and fruit quality of "Le Conte" pear trees. American Journal of Experimental Agriculture, 9(4):1-9.

Nabil, W. A.; M. M. Nasr and A. S. Wally (2013). Effect of gibberellic acid alone or combined with two antioxidants on fruit set, yield and fruit quality of "Hollywood" and "Golden Japanese" plum cultivars. Egypt. J. Hort., 40(1):121 - 132.

Sasaki, K. and N. Utsunomiya (2002). Effect of combined application of CPPU and $\mathrm{GA}_{3}$ on the growth of 'Irwin' mango fruits. Japanese Journal of Tropical Agriculture, 46(4):224 - 229.

Snedecor, G. W. and W. G. Cochran (1990).Statistical methods. 7th Ed. Iowa State Univ. Press. Ames., Iowa, USA, p. 593.

Stern, R. A.; R. Ben-Arie; O. Neria and M. A. Flaishman (2003). CPPU and BA increase fruit size of 'Royal Gala' (Malus domestica) apple in a warm climate. Journal of Horticultural Science \& Biotechnology, 78(3):297 - 302.

Stern, R. A.; R. Ben-Arie; S. Applebaum and M. A. Flaishman (2006). Cytokinins increase fruit size of 'Delicious' and 'Golden Delicious' (Malus domestica) apple in a warm climate. Journal of Horticultural Science and Biotechnology, 81(1): 51-56.

Susila, T.; S. A. Reddy; M. Rajkumar; G. Padmaja and P. V. Rao (2013). Studies on exogenous application of CPPU and $\mathrm{GA}_{3}$ on yield, fruit quality character and seedlessness in watermelon. World Journal of Agriculture Sciences, 9 (2): 132 - 136.

Yahata, S.; M. Miwa; H. Ohara; K. Ohkawa and H. Matsui (2006). Effect of application of gibberellins in combination with forchlorfenuron (CPPU) on induction of seedless fruit set and growth in triploid loquat. Acta Hort., 727:263 268.

Yamamura, H.; K. Matsui and T. Matsumoto, T. (1989). Effects of gibberellins on fruit set and flower-bud formation in unpollinated persimmons (Diospyros kaki). Scientia Hort., 38(1-2):77 - 86.

Yehia, T. A. and H. S. Hassan (2005). Effect of some chemical treatments on fruiting of 'Leconte' pears. Journal of Applied Sciences Research, 1(1):35 - 42 .

Zoffoli, J. P.; B. A. Latorre and P. Naranjo (2009). Preharvest applications of growth regulators and their effect on postharvest quality of table grapes during cold storage. Postharvest Biology and Technology, 51(2):183 - 192. 


\section{تأثير الرش بالجبرلين و السيتوفكس على المحصول و جودة ثمار أثجار البرقوق صنف كلزى. \\ حن أبو الفتوح عناب و هثام محمد أبو عجيلة

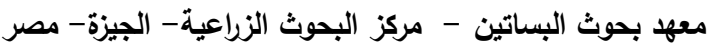

أجريت تجربة خلال موسمي 2018 و 2019 في مزرعة خاصة بأبو المطامير - محافظة البحيرة - مصر . لدراسة تأثير رش حمض

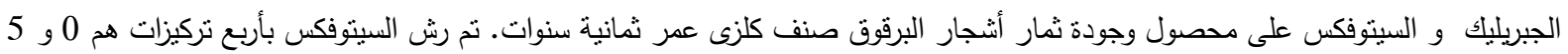

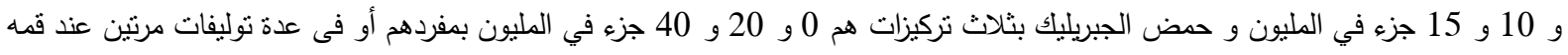

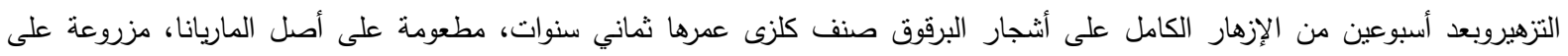

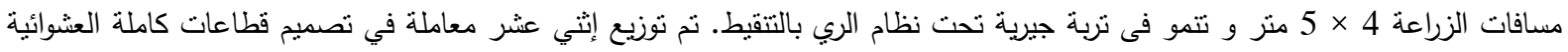

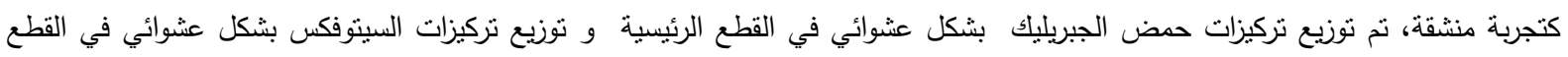

المنشقة.

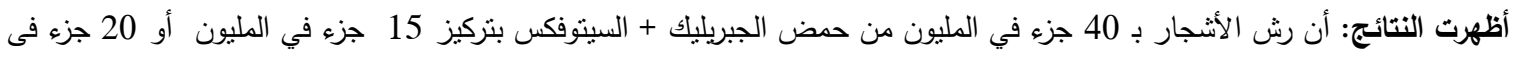
المليون من حمض الجبريليك + 15 جزء فى المليون من السيتوفكس أديا إلى زيادة معنوية فى نسبة عقد الثمار و النسبة المئوية للثمار كبيرة

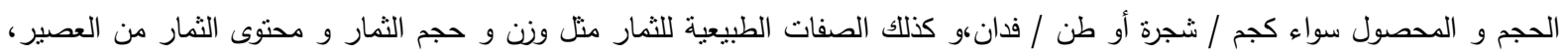

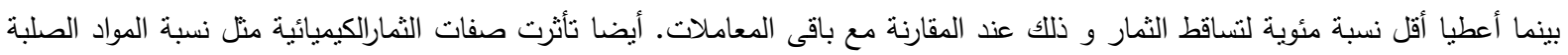

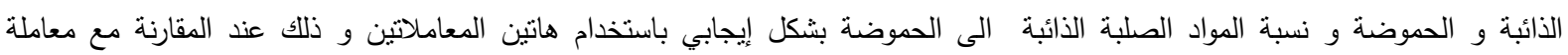

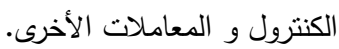
و بناء علية يمكن التوصية برش أثنار البرقوق صنف كلزى باستخدام 40 جزء في المليون من حمض الجبرئيليك + السيتوفكس بتركيز

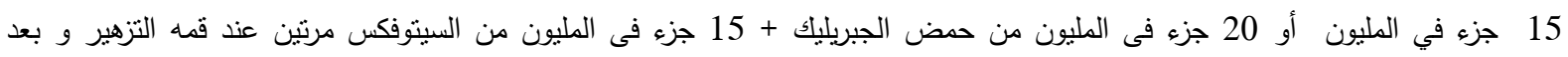

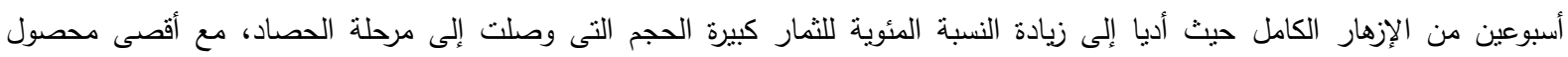

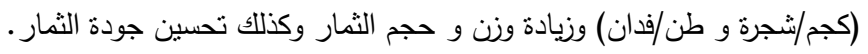

